\title{
EFFECT OF PRNP GENE POLYMORPHISM ON REPRODUCTIVE PERFORMANCE OF MOTHER SHEEP AND THEIR OFFSPRING GROWTH
}

\author{
TOMASZ M. GRUSZECKI, MONIKA GREGUŁA-KANIA, ROMAN NIŻNIKOWSKI ${ }^{1}$, \\ MIROSŁAW PIĘTA, KRZYSZTOF KOSTRO ${ }^{2}$, ANNA SZYMANOWSKA, \\ ANNA MIDUCH, AND EWA STRZELEC ${ }^{1}$
}

Department of Small Ruminants Breeding and Agriculture Advisory, Faculty of Biology and Animal Breeding, University of Life Sciences in Lublin, 20-950 Lublin,

${ }^{1}$ Department of Sheep and Goat Breeding, Faculty of Animal Science,

Warsaw University of Life Sciences-SGGW in Warsaw, 02-786 Warsaw,

${ }^{2}$ Department of Epizootiology and Clinic of Infections Diseases, Faculty of Veterinary Medicine,

University of Life Sciences in Lublin, 20-033 Lublin

tomasz.gruszecki@up.lublin.pl

Received: December 15, 2011

Accepted: August 30, 2012

\begin{abstract}
The polymorphism of prion protein $(\mathrm{PrP})$ amino acids in codons $136(\mathrm{~A} / \mathrm{V}), 154(\mathrm{R} / \mathrm{H})$; and $171(\mathrm{Q} / \mathrm{R} / \mathrm{H})$ was established. Reproductive performance of mother sheep was evaluated analysing the fertility coefficient and litter size, i.e. the number of born and reared lambs. The studies included mothers of synthetic lines BCP - 111 sheep and SCP - 104 sheep born in 2001-2007. In the examined ovine $P R N P$ gene, the following four alleles were identified: $A R R, A H Q, A R Q$, and $V R Q$, with the absence of the $A R H$ allele. The highest frequency was determined for the $A R R(49.8 \%)$ and $A R Q(45.8 \%)$ alleles. In the studied sheep population, the occurrence of seven different genotypes was reported. It was found that $71.6 \%$ of the animals had the genotypes $A R R / A R R$, $A R R / A R Q$, and $A R R / A H Q$, which are regarded as the most resistant to scrapie, while $7.9 \%$ of the population had $A R R / V R Q$-bearing genotypes (low resistance) or $A R Q / V R Q$ ones (high susceptibility to scrapie). The analysis of the obtained results indicates that the $P R N P$ genotype does not affect reproduction efficiency of mothers, or their offspring growth. It was concluded that flock elimination of ewes of genotypes with high and very high susceptibility to scrapie will not reduce the reproduction parameters of ewes or growth of their lambs.
\end{abstract}

Key words: ewes, lambs, scrapie, reproduction, lamb growth, $P R N P$ gene.

Mutations within the locus PrP prion protein gene are associated with the incidence of clinical scrapie $(1,12)$. It is one of the neurodegenerative diseases reported in sheep. The first description of its clinical manifestations appeared in 1759 but it was not considered a disease entity until the 30-ties of the last century (17). The law rules established in the EU (999/2001/EC), (2003/100/ EC), (260/2003/EC) impose the member states obligation to undertake efforts aiming at protection of the managed sheep breeds against scrapie.

The available literature provides a comprehensive overview of scientific papers on the PRNP gene polymorphism in different breeds of sheep $(5,7,8,10,11,16,19)$. These papers describe the proportion of animals with genotypes regarded as susceptible and sensitive to scrapie, and point at the need of final elimination of sheep with sensitive genotypes from the flocks. However, realisation of such programme may bring adverse results, causing a reduction of breeding performance. Thus, the relationship between PRNP genotypes and some performance traits need to be elucidated. The objective of the presented study was to analyse sheep reproductive performance and the growth of their offspring in relation to the polymorphic form of the PRNP gene within the codons 136,154 , and 171 occurring in their mothers.

\section{Material and Methods}

The study involved ewes of universal synthetic BCP (111 animals) and SCP (104 animals) lines, born in 2001-2007 (3). Growth of offspring was analysed based on body weight of 996 lambs. The genomic DNA was isolated from blood using the commercial kit for isolation (A\&A Biotechnology, Poland) according to the procedure recommended by the producer. The polymorphism of prion protein amino acids was established $(\operatorname{PrP})$ in codons $136(\mathrm{~A} / \mathrm{V}), 154(\mathrm{R} / \mathrm{H})$, and $171(\mathrm{Q} / \mathrm{R} / \mathrm{H})$. The samples were amplified and genotyped using the KASPar technology (www.kbioscience.co.uk). The PCR primers for 
amplification of specific DNA sequences were used according to the procedure described by Lityński et al. (8). Frequency of genotypes and alleles of the PRNP gene were determined in the studied populations. Reproductive performance of mother sheep was evaluated analysing the fertility coefficient and litter size, i.e. the number of born and reared lambs.

The statistical analyses involved the leastsquares variance analysis (SAS 9.1.3 2003). In the model for reproduction traits: synthetic line (BCP, SCP), scrapie susceptibility/resistance group (I-V), and succeeding reproduction efficiency years were included. A separate analysis, focusing on the growth of born lambs included: effect of synthetic line, scrapie susceptibility/resistance group (I-V), succeeding reproduction efficiency years (1-7), birth type $(1,2)$, and sex. Data illustrating the trait values obtained for the mother groups of defined scrapie sensitivity/susceptibility are summarised in the tables presenting the least square means (LSM) and standard errors (SE).

\section{Results}

The applied molecular analyses resulted in detection of five alleles of the PRNP gene, i.e. $A R R$, $A R Q, A H Q, A R H$, and $V R Q$. In the present study, the following four alleles in the $P R N P$ gene were identified: $A R R, A H Q, A R Q$, and $V R Q$, whereas no $A R H$ allele was reported (Table 1). The highest frequency was determined for the allele $A R R \quad(49.8 \%)$ and $A R Q$ (45.8\%). A similar tendency was observed when each line was analysed separately, namely in the BCP line the $A R R$ allele $(54.5 \%)$ was predominant when $A R Q$ constituted $39.2 \%$, and in the SCP the $A R Q$ allele was more frequent $(52.0 \%)$ while $A R R$ constituted $45.3 \%$. The allele $A H Q$ rarely occurred in the studied population $(0.5 \%)$, and it was present only in the sheep of BCP line.

In the studied sheep population, seven different genotypes were determined, which were allocated according to Dawson et al. (2) into risk classes of scrapie susceptibility (Table 2). A total of 154 ewes were classified into classes I and II (the most resistant), which accounted for $71.6 \%$ of all the investigated animals. In the BCP line ewes, $74 \%$ of animals were found in the risk classes I and II, and in case of the animals from SCP line $69.4 \%$ belonged to these two groups.

Class III (low scrapie resistance) comprised 44 animals that represented $20.5 \%$ of the studied population. Higher frequency of these genotypes was reported in the SCP line $-25.2 \%$ as compared to the BCP $-15.4 \%$. Class IV - low resistance, and class V high scrapie susceptibility consisted of 17 ewes, that is $7.9 \%$ of the population. It is noteworthy, that the most sensitive genotypes were more frequently observed in the BCP line sheep - frequency $10.6 \%$, as compared to $5.4 \%$ frequency in the SCP line.

Table 1

Allele frequency (\%) of PRNP gene in sheep of BCP and SCP synthetic lines

\begin{tabular}{ccccccccc}
\hline \multicolumn{2}{c}{ Allele } & $A R R$ & $A R H$ & $A H Q$ & $A R Q$ & VRQ & Total \\
\hline \multirow{2}{*}{ BCP } & $\mathrm{n}$ & 114 & 0 & 2 & 82 & 11 & 209 \\
\cline { 2 - 9 } & Frequency & 54.5 & 0.0 & 1.0 & 39.2 & 5.3 & 100 \\
\hline \multirow{2}{*}{ SCP } & $\mathrm{n}$ & 100 & 0 & 0 & 115 & 6 & 221 \\
\cline { 2 - 9 } & Frequency & 45.3 & 0.0 & 0.0 & 52.0 & 2.7 & 100 \\
\hline \multirow{2}{*}{ Total } & $\mathrm{n}$ & 214 & 0 & 2 & 197 & 17 & 430 \\
\cline { 2 - 9 } & Frequency & 49.8 & 0.0 & 0.5 & 45.8 & 3.9 & 100 \\
\hline
\end{tabular}

Table 2

Frequency (\%) of PRNP genotypes in mother sheep of synthetic lines BCP and SCP

\begin{tabular}{|c|c|c|c|c|c|c|c|}
\hline \multicolumn{2}{|c|}{ Resistance class } & I & II & III & IV & $\mathrm{V}$ & \multirow[b]{2}{*}{ Total } \\
\hline \multicolumn{2}{|c|}{ Genotype } & $A R R / A R R$ & $\begin{array}{l}A R R / A R Q \\
A R R / A H Q\end{array}$ & $\begin{array}{l}A R Q / A R Q \\
A H Q / A R Q\end{array}$ & $A R R / V R Q$ & $A R Q / V R Q$ & \\
\hline \multirow{2}{*}{$\mathrm{BCP}$} & $\mathrm{n}$ & 31 & 46 & 16 & 5 & 6 & 104 \\
\hline & Frequency & 29.8 & 44.2 & 15.4 & 4.8 & 5.8 & 100 \\
\hline \multirow{2}{*}{ SCP } & $\mathrm{n}$ & 20 & 57 & 28 & 3 & 3 & 111 \\
\hline & Frequency & 18.0 & 51.4 & 25.2 & 2.7 & 2.7 & 100 \\
\hline \multirow{2}{*}{ Total } & $\mathrm{n}$ & 51 & 103 & 44 & 8 & 9 & 215 \\
\hline & Frequency & 23.7 & 47.9 & 20.5 & 3.7 & 4.2 & 100 \\
\hline
\end{tabular}


Table 3

Reproductive performance of mother sheep according to scrapie resistance classes

\begin{tabular}{|c|c|c|c|c|c|c|c|}
\hline \multicolumn{3}{|c|}{ Susceptibility class } & I & II & III & IV & V \\
\hline \multicolumn{3}{|c|}{$\begin{array}{l}\text { Number of matings in successive } \\
\text { years of reproductive utilisation }\end{array}$} & 173 & 350 & 130 & 26 & 31 \\
\hline \multirow{2}{*}{\multicolumn{2}{|c|}{ Fertility (\%) }} & LSM & 86.2 & 89.1 & 85.0 & 81.4 & 87.5 \\
\hline & & SE & 3.0 & 2.2 & 3.4 & 7.4 & 7.9 \\
\hline \multirow{4}{*}{$\begin{array}{l}\text { Litter } \\
\text { size }\end{array}$} & \multirow{2}{*}{ born } & LSM & 1.81 & 1.82 & 1.84 & 1.69 & 2.09 \\
\hline & & SE & 0.05 & 0.04 & 0.06 & 0.13 & 0.12 \\
\hline & \multirow{2}{*}{ reared } & LSM & 1.59 & 1.61 & 1.63 & 1.48 & 1.78 \\
\hline & & SE & 0.05 & 0.04 & 0.07 & 0.14 & 0.14 \\
\hline
\end{tabular}

Table 4

Body weight of lambs from mother sheep of synthetic lines BCP and SCP according to scrapie susceptibility classes

\begin{tabular}{|c|c|c|c|c|c|c|c|}
\hline & eptibility & & I & II & III & IV & $\mathrm{V}$ \\
\hline \multirow{9}{*}{$\begin{array}{l}\text { Lamb } \\
\text { body } \\
\text { weight } \\
(\mathrm{kg})\end{array}$} & \multirow{3}{*}{ at birth } & $\mathrm{n}$ & 234 & 507 & 181 & 31 & 43 \\
\hline & & LSM & $491^{\mathrm{A}}$ & 5.4 & $4.94^{\mathrm{B}}$ & $5.40^{\mathrm{ABC}}$ & $4.77^{\mathrm{C}}$ \\
\hline & & $\mathrm{SE}$ & 0.06 & 0.05 & 0.07 & 0.15 & 0.15 \\
\hline & \multirow{3}{*}{$\begin{array}{c}28 \mathrm{~d} \text { of } \\
\text { age }\end{array}$} & $\mathrm{n}$ & 196 & 422 & 157 & 25 & 29 \\
\hline & & LSM & $11.8^{\mathrm{a}}$ & 12.2 & $11.8^{\mathrm{b}}$ & $13.0^{\mathrm{abc}}$ & $11.5^{\mathrm{c}}$ \\
\hline & & $\mathrm{SE}$ & 0.20 & 0.16 & 0.23 & 0.49 & 0.56 \\
\hline & \multirow{3}{*}{$\begin{array}{c}56 \mathrm{~d} \text { of } \\
\text { age }\end{array}$} & $\mathrm{n}$ & 101 & 228 & 77 & 8 & 17 \\
\hline & & LSM & 19.8 & 19.6 & 19.8 & 19.9 & 18.3 \\
\hline & & SE & 0.61 & 0.51 & 0.67 & 1.53 & 1.59 \\
\hline
\end{tabular}

$\mathrm{A}, \mathrm{B}, \mathrm{C}-\mathrm{P} \leq 0.01$

a, b, c- $\mathrm{P} \leq 0.05$; means within lines with the same superscript differ significantly.

Fertility rate ranged from $81.4 \%$ up to $89.1 \%$, and no relationship between this trait value and allocation to the susceptibility class was reported (Table 3).

Growth of offspring obtained from the studied ewes was analysed on the grounds of lamb body weight (BWT) at birth, and on the $28^{\text {th }}$ and $56^{\text {th }}$ day of age (Table 4). Lambs produced by ewes from the IV resistance class had the highest BWT at birth $(5.4 \mathrm{~kg})$, whereas the lowest values $(4.7 \mathrm{~kg})$ were observed in offspring from ewes assigned into class V. The noted difference proved to be statistically significant $(\mathrm{P} \leq 0.01)$. The lambs obtained from mothers classified into class IIII were characterised by similar body weight at birth $(4.91-5.04 \mathrm{~kg})$ and the values were significantly $(\mathrm{P} \leq 0.01)$ lower as compared to the offspring from mothers from class IV. The lambs from mothers in class IV were still the heaviest ( $13 \mathrm{~kg}$ ) at the age of $28 \mathrm{~d}$, thus, exceeding significantly $(\mathrm{P} \leq 0.05)$ the BWT of the lambs from mothers in classes I, II, and V, whose weight ranged between 18.3 and $19.9 \mathrm{~kg}$. At the age of $56 \mathrm{~d}$, the differences between lambs obtained from mothers in classes I-V were not statistically significant.

\section{Discussion}

Special attention should be paid to the frequency of the $V R Q$ allele, which is considered as a marker of very high susceptibility to scrapie. This value appeared to be low $(3.9 \%)$ in the studied population, yet higher frequency was noted in the BCP $(5.3 \%)$ in comparison to the SCP $(2.7 \%)$ line. Distribution frequency of each allele form of the PRNP gene in sheep of synthetic lines BCP and SCP were similar to that determined in most indigenous Polish sheep breeds (10). The present study has shown that the frequency of PRNP genotypes in the sheep of BCP and SCP lines with classification into risk classes resembles the frequency in the Polish Merino and Polish Lowland sheep (7). The analysis of the presented results regarding the genotype frequency indicates a substantial proportion of the desirable $A R R$ allele in both homozygous and heterozygous conditions. In addition, it was determined that only a small number of animals carrying scrapie susceptible genotypes allocated to IV and $\mathrm{V}$ risk class. Thus, the authors consider the situation to be advantageous for the breeding policy, as the genotype distribution clearly indicates the possibility of efficient genetic-based selective breeding leading to 
sheep flocks free from animals with alleles and genotypes susceptible to scrapie. This is in line with the results of other studies, which confirmed the possibility of increasing the frequency of genotypes resistant to scrapie up to $99.57 \%$ through genetic selection operations $(15,18)$. Elimination of sheep with susceptible genotypes is also regarded as a proper management tool for scrapie prevention and control in Germany and the Netherlands (6, 9). Importantly, the results of Hoinville et al. (4), showing that scrapie infections are transmitted from mothers to their offspring, have also supported the purposefulness and usefulness of such measures.

Litter size at birth and by the end of the lamb rearing period was also shown not to be significantly dependent on scrapie risk class. The performed analysis allowed to state that culling animals from IV and V scrapie resistance classes will not affect the reproductive performance parameters. The studies conducted on Belclare sheep (14), and on German meat sheep breeds (19) did not show impact of genotype in locus PRNP on litter size.

Tongue et al. (16) displayed a positive effect of the $A R R$ allele on lamb body weight at birth, which was higher by $0.3 \mathrm{~kg}$ at average, whereas in $V R Q$ allelebearing genotypes it was significantly lower by $0.6 \mathrm{~kg}$. Ioannides et al. (5), determined that ewe's genotype was associated with the performance of reproductive traits but not with total weight of lamb at birth or at weaning.

The next analysed trait - growth of offspring was not significantly dependent on scrapie risk class of their mothers. The higher body weight of lambs obtained from mothers of IV class (Table 4) resulted from a slightly lower value of litter size (Table 3). Different results were obtained in German Blackface sheep where the beneficial association of the $A R R$ allele with daily weight gain and higher longest dorsal muscle depth was found (20). In summary of the results obtained in the present study, the authors conclude that a defined PRNP genotype does not affect the reproductive performance parameters of ewes or their offspring growth. Therefore, the realisation of EU law rules (999/2001/EC; 2003/100/ EC; 260/2003/EC) demanding the elimination of ewes of high and very high susceptibility to scrapie will not contribute towards a decrease in the traits values in the flock.

\section{References}

1. Collinge J.: Prion diseases of humans and animals: their causes and molecular basis. Annu Rev Neurosci 2001, 24, 519-550.

2. Dawson M., Moore R.C., Bishop S.C.: Progress and limits of PrP gen selection Policy. Vet Res 2008, 39, 25 37.

3. Gruszecki T.M., Lipecka C.: Animal breeds in Poland. Versatile synthetic lines BCP and SCP- characteristics. Medycyna Wet 2009, 65, 215.

4. Hoinville L.J., Tongue S.C., Wilesmith J.W.: Evidence for maternal transmission of scrapie in naturally affected flocks. Prev Vet Med 2010, 93, 121-128.
5. Ioannides I.M., Mavrogenis A.P., Papachristoforou C.: Analysis of PrP genotypes in relation to reproductive and production traits in Chios sheep. Livest Sci 2009, 122, 296-301.

6. Kaal L., Windig J.: Rare Steep breeds and breeding for scrapie resistance in the Netherlands. $56^{\text {th }}$ EAAP, Uppsala, Sweden, 2005, p. 375.

7. Kawecka M.: The genetic structure of selected conservative sheep breeds susceptible to scrapie (Pomeranian sheep, Polish lowland sheep, Wrzosówka sheep) and in Polish Mountain sheep, and Merino. PhD Thesis, Instytut Zootechniki, Balice k. Krakowa, 2010.

8. Lityński R., Niżnikowski R., Popielarczyk D., Strzelec E., Głowacz K.: PRNP gene polymorphisms in Polish population of East-Friesian milk sheep. Anim Sci 2009, 46, 295-299.

9. Lühken G., Buschmann S., Groschup M.H., Erhardt G.: Prion protein allele A136H154Q171 is associated with high susceptibility to scrapie in purebred and crossbred German Merinoland sheep. Arch Virol 2004, 149, 1571 158.

10. Niżnikowski R., Lühken G., Strzelec E., Lipsky S., Popielarczyk D., Erhardt G., Consortium Ekonogene. PRNP gene polymorphism in codons 136, 154, and 171 in Polish sheep breeds. Medycyna Wet 2006, 62, 938941.

11. Psifidi A., Basdagianni Z., Dovas C. I., Arsenos G., Sinapis E., Papanastassopoulou M., Banos G.: Characterization of the PRNP gene locus in Chios dairy sheep and its association with milk production and reproduction traits. Anim Genet 2011, 42, 406-414

12. Rejduch B. Choroby prionowe. Encefalopatia gąbczasta mózgu u owiec: genetyczne aspekty scrapie, diagnostyka i program hodowlany. IZ-PIB Kraków, 2008.

13. SAS Institute, Incorporated C N U SAS user's guide statistics: Version 9.1.3. Cary N.C., 2003.

14. Sweeney T., Hanrahan J.P., O'Doherty E.: Is there a relationship between prion protein genotype and ovulation rate and litter size in sheep? Anim Reprod Sci 2007, 101, 153-157.

15. Szkudlarek-Kowalczyk M., Wiśniewska E., Mroczkowski S.: Prion protein gene (PRNP) polymorphism in a Kamieniecka sheep population. Bull Vet Inst Pulawy 2010, 54, 645-649.

16. Tongue S.C., Pfeiffer D.U., Heasman L., Simmons H., Ryder S.J.: PrP genotype and lamb birth weight in a scrapie-free environment: Is there an association? Livest Sci 2006, 105, 120-128.

17. Wickner R.B., Edskes H.K., Roberts B.T., Baxa U., Pierce M.M., Ross E.D., Brachmann A.: Prions: proteins as genes and infection entities. Gene Dev 2004, 18, 470485.

18. Wiśniewska E., Mroczkowski S.: Prion protein (PrP) gene polymorphisms and simulation study of scrapie resistance breeding in Polish Merino and Polish Mountain sheep. Roczn Nauk Pol Tow Zootechn 2010, 6, $115-123$

19. de Vries F., Hamann H., Drögemüller C., Ganter M., Distil O.: Analysis of associations between the prion protein genotype and reproduction traits in meat sheep breeds. Anim Sci 2004, 79, 397-404.

20. de Vries F., Borchers N., Hamann H., Drögemüller C., Reinecke S., Lüpping W., Distl O.: Associations between the prion protein genotype and performance traits of meat breeds of sheep. Vet Rec 2004, 155, 140143. 